\title{
International Federation for Emergency Medicine Model Curriculum for Emergency Medicine Specialists
}

\section{Özet}

Uluslararası Acil Tıp Federasyonu (International Federation for Emergency Medicine-IFEM) hekimlerin mezuniyet sonrası acil tıp alanında uzmanlık gördükleri eğitimin temel minimum standartlarını tanımlamak üzere "Model Curriculum for Emergency Medicine Specialists" başlıklı kılavuzunu 2010 yılında yayınladı. ${ }^{[1]}$ Bu kılavuz farklı ülkelerden katılan çok sayıda acil hekimi, sağlık çalışanı ve acil tıp alanındaki diğer uzmanların katıımı ile oluşan IFEM Çekirdek Müfredat ve Eğitim Komitesi tarafından hazırlandı. Aynı komitenin hazırlandığı ve Ekim 2009'da yayınlanan mezuniyet öncesi tıp eğitiminde acil tıp çekirdek müfredatı Türkiye Acil Tıp Dergisi'nin Aralık 2009 sayısında yayınlanmıştı ${ }^{[2]}$ Uzmanlık eğitimi için hazırlanan bu model müfredatın acil tıp uzmanlık eğitiminin yapılandırılmasında ve standardizasyonunda kullanılabilecek yararlı bir kaynak olacağı için derginin bu sayısında orijinal tam metin olarak yayınlanmaktadır. Bu makalede, yayınlanan kılavuz hakkında özet bazı bilgileri sizlerle paylaşacağım.

\section{Giriş}

Tüm dünyada acil hekimi ve acil tıp kaynaklarının kritik ve artan ihtiyacını karşılamak için hekimler, zamana duyarlı girişimleri ve hayat kurtarıcı bakımı vermek için eğitilmelidir. Henüz dünya çapında tanınan, acil tıp uzmanlık eğitimi için temel minimum standartları tanımlayan standart bir müfredat mevcut değildir. Bu eksikliği gidermek için IFEM Çekirdek Müfredat ve Eğitim Komitesi bir müfredat taslağı hazırlamıştır. Bu müfredat acil tıp eğitim programları için bir iskelet yapı oluşturmayı hedeflemiştir. Hedef, acil tıp uzmanlık eğitimini tamamlayan bir acil tıp uzman hekiminin bilgi sahibi olması gereken temel minimum acil tıp eğitiminin içeriğinin belirlenmesidir. Kılavuz salt bu hali ile uygulanmak için değil, eğitim yeri neresi olursa olsun eğitimcilere ve acil tıp liderlerine yardımcı olmak için hazırlanmıştır. Bu kılavu- zun içeriği acil tıp sistemlerinin gelişmiş olduğu ülkeler yanında, acil tıbbın gelişmekte olduğu veya gelişme arayışlarının sürdüğü ülkeler için de uyumludur.

\section{Yönetici Özeti}

Bu bölümde komite uluslararası müfredatın geliştirilmesinin kısa bir açıklamasını yapmış ve bu önemli girişimin vizyonunu, gerekçesini, ihtiyacını, amacını, kaynaklarını ve ilerleyişini tanımlamışlardır.

Acil tıp alanında az sayıda ülkede halen müfredat mevcuttur ve uluslararası bir müfredat tanımlanmamıştır. Dünyada 100'den fazla ülke acil tıp alanında gelişim süreci içindedir. Mevcut müfredatlar gözden geçirilerek minimum temel ihtiyaçlara ulaşma stratejisi benimsenmiştir. En iyi acil bakımının verilmesi için hekimlerin, sağlık çalışanlarının eğitimini teşvik etmek için müfredat belirlenmiştir. ACEP, CEM, EUSEM ile birçok ülkenin ve uluslararası üyeliği olan Acil Tıp dernekleri dâhil IFEM üyesi derneklerden, üniversitelerden ve Acil Tıp eğitimi veren bölümlerden ilgi ve desteğe atfen bu ürün ortaya çıkmıştır.

\section{Misyon Cümlesi}

IFEM, 1991 yılında Acil Tıbbın tanımını (bkz.: http://www. ifem.cc/About_IFEM.aspx) yapmıştır. Acil tıp; olağandışı ayırt edilmemiş fiziksel ve davranışsal rahatsızlıkların bütün spektrumu ile tüm yaş gruplarını etkileyen hastalık ve yaralanmaların akut ve acil durumlarının önlenmesi, tanısı ve yönetimi için gerekli olan bilgi ve becerilere dayalı bir uygulama alanıdır; hastane öncesi ve hastane içi acil tıbbi sistemlerinin gelişimini ve gelişimi için gereken becerileri anlamayı da kapsar.

Hekimlerin hizmet verdiği toplum, sık görülen çok sayıdaki tıbbi ve cerrahi problemlerin yönetimi için, uzmanlık eğiti- 
minin sonucu hekimlerin kapsamlı bir acil bakım bilgisine ve acil girişim becerisine sahip olduğunu bekleme hakkına sahiptir. Uzmanlık eğitimi tamamlandığı zaman, acil tıp uzmanı hekim aşağıdaki özeliklere sahip olmalıdır:

- Acil bir durumda, acil durumun yerinden bağımsız olarak kapsamlı, acil ve stabilize edici bakımı verebilmelidir.

- Zaman baskısı altında karar vermenin hayat kurtarmak için gerekli olduğu durumları yönetebilmelidir.

- İlk geçici tanıyı ve ayırıcı tanıları ve hayatı tehdit eden durumları tespit edebilmelidir.

- Sertifika veren kurumun akademik çatısı içinde tanımlanan bilgi, beceri ve davranış ustalığını gösterebilmeli ve onay kriterlerinin ve akademik sınav gerekliliklerinin her birini ve tümünü karşılayabilmelidir.

- Olağandışı ayırt edilmemiş fiziksel ve davranışsal belirtilerin ve/veya rahatsızlıkların bütün spektrumu ile başvuran akut ve acil hastalık ve yaralanmaları olan tüm yaş gruplarındaki hastaları yönetebilmelidir.

- Kitlesel yaralanmalı olaylar dâhil aynı anda çok sayıda hastanın yönetiminin koordinasyonu ve idaresinde ehil olmalıdır.

- Başka bir uzman ile konsültasyonun gerekli olduğu zamanı belirleyebilmelidir.

- Hastanın savucusu, danışmanı olarak davranabilmeli ve hastalık veya yaralanmasının akut döneminde yol gösterebilmelidir.

- Tüm diğer sorunlardan önce hasta bakımı için bağlılığını gösterebilmelidir.

\section{Acil Tıpta Bir Uzmanın Mesleki Gelişimi}

Bu bölümde uzmanlık eğitimi sırasında, eğitim alan kişinin geliştirmesi, uygulaması, göstermesi, bilmesi ve tanıması gereken birçok özellik sıralanmıştır. Özetle; eski tıp bilgilerinin acil tıbba aktarılması, klinik ve uygulama becerilerini geliştirmesi, zaman içinde hasta sorumluluğunu daha fazla oranda alması ve klinik durumları iyi analiz edebilmesi beklenmektedir. Bu özellikle içinde vurgulanması gereken birkaç nokta ise acil girişim becerilerinin çocuklar dâhil tüm yaş grupları için yeterli şekilde kazanılması gerektiğidir. Hastane öncesi dâhil tüm çalışanlar, hastalar ve aileleri ile iyi iletişim becerileri gösterebilmelidir. Sağlık hizmetlerinin sunumunun kalitesinin iyileştirilmesi için çaba harcamalıdır. Araştırma yapabilmelidir. Ekip çalışmalarında yönetici veya ekibin parçası olarak çalışabilmelidir. Acil bakımda kendi sınırlarını bilmelidir. Hastanın, toplumun, acil tıbbın savunucusu olmalıdır.

\section{Eğitimin Yapısı}

Eğitim yapılandırılmalıdır. Eğitilenler çekirdek rotasyonların öğrenim hedefleri ile iyi dizayn edilmiş bir programa sahip olmalıdır. Eğitilenlerin tümü acil tıp uzmanlığı için gereken bilgi, beceri ve davranışlardaki yeterliliğin ölçümü için oluş- turulmuş kapsamlı bir değerlendirme ve ölçme yeteneğine sahip sınavlara alınmalıdır.

Eğitim vermek üzere onay almış bir acil tıp eğitim programında, en az 3 yıllık bir eğitim süresinin tamamlanması önerilmektedir. Bu süre eğitim ihtiyacına göre modifiye edilebilir. Hastalıkların sıklığı, hasta çeşitliliği, eğitim modellerine göre daha uzun süreler uygulanabilir. Tablo 1'de seçilmiş bazı ülkelerin ulusal müfredatları karşılaştırmak üzere verilmiştir. Tabloda da görülebileceği gibi eğitim süreleri, anestezi dâhil yoğun bakım eğitimi, cerrahi ve dahili branşlardaki eğitim rotasyonları, çocuk hasta bakımı, hastane öncesi acil sağlık hizmetleri, afet ile ilgili eğitim ile araştırma ve elektif rotasyon süreleri karşılaştırılmıştır.

\section{Eğitim Ortamı}

\section{Klinik alan}

Uzmanlık eğitiminin klinik alanı, halka mükemmel acil tıbbi bakım sağlayacak nitelikte olmalıdır. Eğitim vermek üzere onay almış bir acil serviste tam zamanlı öğretim üyesi görev yapmalıdır. En az veya en çok hasta sayısının ne olması gerektiği hakkında bu kılavuzda yorum yapılmamıştır, ancak eğitilen kişinin tüm yaş gruplarından ve cinsiyetten, farkI özellikte klinik sorunları olan yeterli sayıda hasta görülmesi önerilmektedir.

Eğitim alanı laboratuar ve tanısal görüntüleme birimlerine sahip olmalıdır. Ek olarak, uygun tıbbi kaynaklar, internet erişimi ile ders, seminer ve düzenli değerlendirmelere uygun eğitim alanları mevcut olmalıdır. Tüm eğitim programları mortalite ve morbidite konferansları dâhil klinik performansın düzenli bir şekilde sistematik olarak değerlendirilmesine tabii olmalıdır. İdeal olarak eğitilenlerin, klinik hasta yoğunluğu ve tipi farklı olan eğitim kurumlarını da tanıması/görmesi önerilmektedir.

\section{Öğrenim deneyimi}

Tüm eğitilenler, acil tıp uzmanı olmak için gerekli olan bilgi, beceri ve davranışları kazanmaya odaklı düzenli bir eğitim programının parçası olma şansına sahip olmalıdır. Öğrenimin çoğu klinik uygulamalar sırasında acil tıp öğretim üyesi veya uzmanının süpervizyonunda kazanılmaktadır; ancak diğer öğrenim olanakları da eğitilen için sağlanmalıdır. Bunlar kuramsal eğitimler, olgu konferansları ve sunumları, seminerler, girişim workshopları ve makale saatleridir. Kurum dışında ise yaşam desteği kursları ve beceri laboratuarlarına dayalı öğrenimlerde eğitim programına dâhil edilmelidir. Uzmanlaşmış eğitimin en önemli komponenti acil servistir. Acil servis dışındaki klinik deneyim de önemlidir. Acil servisten yatırılan hastaların bakımından sorumlu ekibin bir parçası olmak da bu bilgi tabanın sağlanmasına yardımcı olur. Yoğun bakım ve anestezi gibi acil servis içinde uygulanan bazı becerilerin öncelikle acil servis dışı alanlarda öğrenilmesi gerekebilir. 
Her eğitim programında yeterli sayıda öğretim görevlisi olmalı ve eğitilenlerin tümüne nezaret etmesi gereklidir. Öğretim görevlileri yeterli zamanını eğitim için ayırmalıdır. En az bir öğretim görevlisi ise "eğitim program direktörü" olarak belirlenmelidir. Eğitim program direktörü tüm öğretim görevlileri, yönetim ve eğitilenler arasındaki irtibat görevlisi olarak hizmet vermelidir. Kurumsal ve klinik eğitimin yürütülmesini izlemelidir.

Program direktörü eğitilenlerin sürekli değerlendirilmesi ve birebir geri bildirimlerinin yapılmasını da sağlamalıdır. Eğitim programı süresince olan ilerlemenin belirtisi olarak performans değerlendirilmesi yapılmalıdır. Eğitilenlerin değerlendirilmesi için çok sayıda yöntem kullanılması önerilmektedir. Hem formatif hem de summatif değerlendirme uygulanmalıdır. Programın iyileştirilmesi gerekli olursa eksikliklerin iyileştirilmesinin planları da yazılı olmalıdır.

\section{Değerlendirme}

Eksiksiz ve doğru değerlendirme eğitim sürecinin olmazsa olmazıdır. Bilgiye dayalı testler yanında simülasyon laboratuvarlarının kullanımı ile beceri ve bilginin ölçüldüğü kompleks interaktif yöntemlerin uygulanması da önerilmektedir. Önerilen ve sık kullanılan eğitim değerlendirme yöntemleri Tablo 2'de özetlenmiştir.

\section{Eğitim Çıktıları ve Öğrenim Hedefleri}

Bu bölümde eğitilenin geliştirmesi, anlaması, uygulayabilmesi ve tanıması gereken bilgi, beceri ve davranışlar listelenmiştir. Havayolu ve solunum yönetimi, dolaşımın desteklenmesi, resusitasyon, travma hastasının yönetimi, yara bakımı, ultrasonografi kullanımı gibi bilgi ve beceri gerektiren tüm konuların bilinmesi ve uygulanabilmesi beklenmektedir. Zehirlenmiş hasta, hastane öncesi tıp, afet yönetimi, dil bariyeri, çevresel hastalık veya yaralanmalar, yaralanmalardan korunma, ani beklenmeyen ölümlerde ölüm haberinin verilmesi, kaynakların kullanımı ve tıbbi karar verme gibi ilintili konularda da uzmanlaşmak beklenmektedir.

\section{Öğrenmenin İçeriği}

IIFEM, üye ülkeleri arasında acil tıp disiplinine özgü içeriğin çoğunun paylaşılmasını beklese de, eğitim içeriğinde bölgesel farklılıkların mevcut olduğunu kabul etmektedir. Tablo 1'de sunulan müfredatlar yanında, spesifik bilgi, beceri ve deneyime göre genel mesleki ve uzmanlığa-özgü içerikleri ile sunulmuştur. Tablo 3'te ise iki önemli eğitim yapısı (CanMEDS ve ACGME), yerel olarak uygulanabilecek müfredatın geliştirilmesi için eğitimcilere sunulmuştur.

Ek olarak, acil tıp için örnek bir eğitim müfredatı ile amaç ve hedeflerin genişletilmiş bir listesi Ek olarak verilmiştir:

Eğitim için acil tıbbın amaç ve hedefleri uzmanlık eğitiminin yıllarına göre ayrı ayrı tanımlanmıştır. Eğitimin her bir yı- lında kişinin öğrenmesi ve geliştirmesi gereken bilgi, beceri ve davranışlar yanında göstermesi gereken yeterliliklerin de tek tek tanımı yapılmıştır. Her yıl için eğitimin tanımı yanında, değerlendirme süreci, geribildirim düzeni ve kaynaklar ile kurumsal özellikler tanımlanmıştır.

Ekte verilen amaç ve hedeflerin her birisini bu özet makalede madde madde vermek uygun olmayacaktır. Ancak eğitim veren tüm öğretim üyelerinin bu önerileri okuması ve kendi eğitim programları için adapte etmesi yerinde olacaktır. Ayrıca, ülkemiz için mevcut olan ulusal acil tıp uzmanlık eğitimi müfredatına bu kılavuzdaki önerilerin eğitim olanaklarımıza göre iyi yorumlanarak eklenmesi ve müfredat güncellemesinin yapılması uygun olacaktır.

\section{Acil Tıp Temel Müfredatının İçeriği}

IFEM, üye ülkelerinin kapsamlı müfredat belgelerinin olduğunu belirtmekte ve herhangi bir müfredat içeriğini diğer ülkelere uygulanması zorunlu bir öneri olarak sunmayı onaylamadığını belirtmektedir.

\section{Ek Okumalar}

Bu bölümde acil tıp uzmanlık eğitimi için yayınlanmış müfredatlar ve farklı ülkelerin eğitim için tanımladığı gerekliliklere ulaşılabilecek kaynaklar verilmiştir.

\section{Sonuç}

Sonuç olarak, acil tıp uzmanlık eğitimi tüm dünyada farklı uygulamalarla verilmektedir. Bölgesel ve ülkelerin sağlık hizmet sunumlarına göre eğitim içerikleri ve süreleri değişse de aynı dili konuşmak adına genel bir standart çerçeyeye ihtiyaç vardır. IFEM'in önerdiği bu kılavuz dikkate alınarak ulusal düzeyde Acil Tıp Uzmanlık Eğitimi Müfredatının güncellenmesi, eğitim veren tüm kurumların yöneticileri ve eğitimcileri bu müfredata uygun bir programın yürütülmesi için hevesli olmalı ve çaba harcamalıdır.

\section{Dr. Cem OKTAY}

Akdeniz Üniversitesi Tıp Fakültesi Acil Tıp Anabilim Dalı, Antalya

\section{Kaynaklar}

1. Hobgood C, Anantharaman V, Bandiera G, Cameron P, Halperin $\mathrm{P}$, Holliman J, Jouriles N, Kilroy D, Mulligan T, and Singer A. International Federation for Emergency Medicine Model Curriculum for Emergency Medicine Specialists. 2010. Available at: http://www.ifem.cc/Resources/IFEM_Curricula_for_ Emergency_Medicine.aspx [accessed Sept 20, 2011].

2. Hobgood C, Anantharaman V, Bandiera G, Cameron P, Halperin $P$, Holliman $J$, Jouriles $N$, Kilroy $D$, Mulligan $T$, and Singer A. International Federation for Emergency Medicine Model Curriculum for Medical Student Education in Emergency Medicine. Canadian Journal of Emergency Medicine 11.4 (July 2009): p349(6). Reprint: Türkiye Acil Tıp Dergisi 2009;9:146-152. 